\title{
Gouty Tophi Mimicking Synovial Sarcoma of the Knee Joint
}

\author{
Diz Ekleminin Sinoviyal Sarkomunu Taklit Eden Gut Tofüsleri \\ Haseeb AMBER, Vivek Ajit SINGH, Mansor AZURA \\ Department of Orthopaedic Surgery, Faculty of Medicine, University of Malaya, Kuala Lumpur, Malaysia
}

\begin{abstract}
Deposition of tophi is a common complication of chronic gout; however, symptoms are not always well pronounced. In this article, we report an unusual case of intraarticular gouty tophi of the knee joint presenting as a locked knee and radiologically mimicking a synovial sarcoma. To our knowledge, gouty tophus causing such a complication (fixed flexion deformity) has not been reported. This case report serves to bring about awareness of an extraordinary presentation of gout, which in severe forms can mimic intraarticular tumors and bring about such a deformity.
\end{abstract}

Key words: Gouty tophi; knee joint; synovial sarcoma.

Gout is defined as the inability to metabolize purine and can present in four different phases: asymptomatic hyperuricemia, recurrent attacks of acute arthritis, intercritical gout, and chronic tophaceous gout. ${ }^{[1,2]}$

If gouty tophus involves soft tissue in the absence of articular disease, the tophi can be mistaken as a neoplastic lesion. ${ }^{[1]}$ However, one has to bear in mind other possible differentials such as tuberculosis, chronic rheumatoid arthritis (RA), amyloidosis, and pigmented villonodular synovitis (PVNS).

Synovial sarcoma is an uncommon malignant neoplasm of the somatic soft tissues which usually affects the extremities and limb girdles, but it also infrequently occurs in the neck and trunk. ${ }^{[3]}$

A locked knee is the inability to fully extend the knee joint, and this is usually due to a sports injury.
Tofüs birikimi, kronik gut hastalığının sık görülen bir komplikasyonudur ancak hastalığın semptomları her zaman belirgin değildir. Bu yazıda kitlenmiş diz olarak kendini gösteren ve radyolojik olarak sinoviyal sarkomu taklit eden, diz ekleminin nadir görülen intraartiküler gut tofüsü olgusu sunuldu. Bilgimiz dahilinde, bu tür bir komplikasyona neden olan gut tofüsü (sabit fleksiyon deformitesi) daha önce bildirilmedi. Bu olgu sunumu, şiddetli formlarda intraartiküler tümörleri taklit edebilen ve bu tür bir deformiteye neden olabilen gutun olağandışı tablosu hakkında farkındalık yaratacak niteliktedir.

Anahtar sözcükler: Gut tofüsü; diz eklemi; sinoviyal sarkom.

Gout and other inflammatory diseases can also cause locked knee due to pain and inflammation, and this is termed as pseudo-locking. Herein, we present a rare case of intraarticular gout in the knee joint that presented with a locked knee due to mechanical blockage.

\section{CASE REPORT}

A 29-year-old male presented with left knee pain and swelling which had been occurring for three years. These symptoms had gotten progressively worse over the last six months. Initially, the pain started at the posterior aspect of the left knee joint, but it gradually progressed to involve the entire knee. The pain was most severe when awakening from sleep, and over time it progressed to stiffness. It affected the patient's range of motion and eventually resulted in locking of the knee. 
In addition, the patient also had a history of right ankle and right elbow joint pain and also had passed out renal calculi associated with hematuria on two occasions two years prior to this presentation.

The patient was diagnosed as having gout five years previously when he had presented with an inflamed right first toe. He was started on medication but was non-compliant, and eventually the patient defaulted on his follow-up.

Physical examination of the left knee revealed tenderness along the anteromedial aspect of the joint, and no effusion was elicited. The attitude of the knee was in a fixed flexion deformity at $30^{\circ}$, and the flexion was up to $100^{\circ}$.

Laboratory investigations were unremarkable with the exception of elevated uric acid levels $(611 \mathrm{umol} / \mathrm{L})$. A plain radiograph of the left knee showed no abnormalities (Figure 1). Subsequently, magnetic resonance imaging (MRI) was ordered to determine the cause of the locked knee, and it showed minimal joint effusion with a hypointense soft tissue mass encasing the anterior cruciate ligament (ACL) and posterior cruciate ligament (PCL) measuring $5.7 \times 1.5 \times 2.2 \mathrm{~cm}$. The MRI of the left knee in the axial, coronal, and sagittal sections revealed a nonspecific mass encasing the left ACL and PCL ligament with minimal joint effusion, which was suggestive of a synovial sarcoma of the left knee joint (Figure 2).

An open biopsy was performed. Intraoperatively, minimal non-hemorrhagic fluid was seen, and the left knee synovium was thickened and inflamed with a chalky white mass within the medial tibiofemoral compartment measuring approximately $1.5 \times 1.5 \times 0.8 \mathrm{~cm}$. Figure 3 shows an intraarticular gouty tophi. Postoperatively, the range of motion improved from $30^{\circ}$ to $160^{\circ}$.

Based on the history and intraoperative findings, a tentative diagnosis of gout was established. Histopathological examination revealed eosinophilic amorphous deposits with focal calcification palisaded by histiocytes and foreign body type giant cells suggestive of gouty tophi.

\section{DISCUSSION}

Gout was not considered as the provisional diagnosis in this case due to the following reasons: 1. Intraarticular tophi lack obvious clinical presentation; 2 . The majority of patients with intraarticular gout would have had a history of gout for 10-12 years before the appearance of radiographic lesions or physical findings (Our case was only diagnosed five years previously.); 3 . Though it's a rare finding, calcification within the tophi is one of the
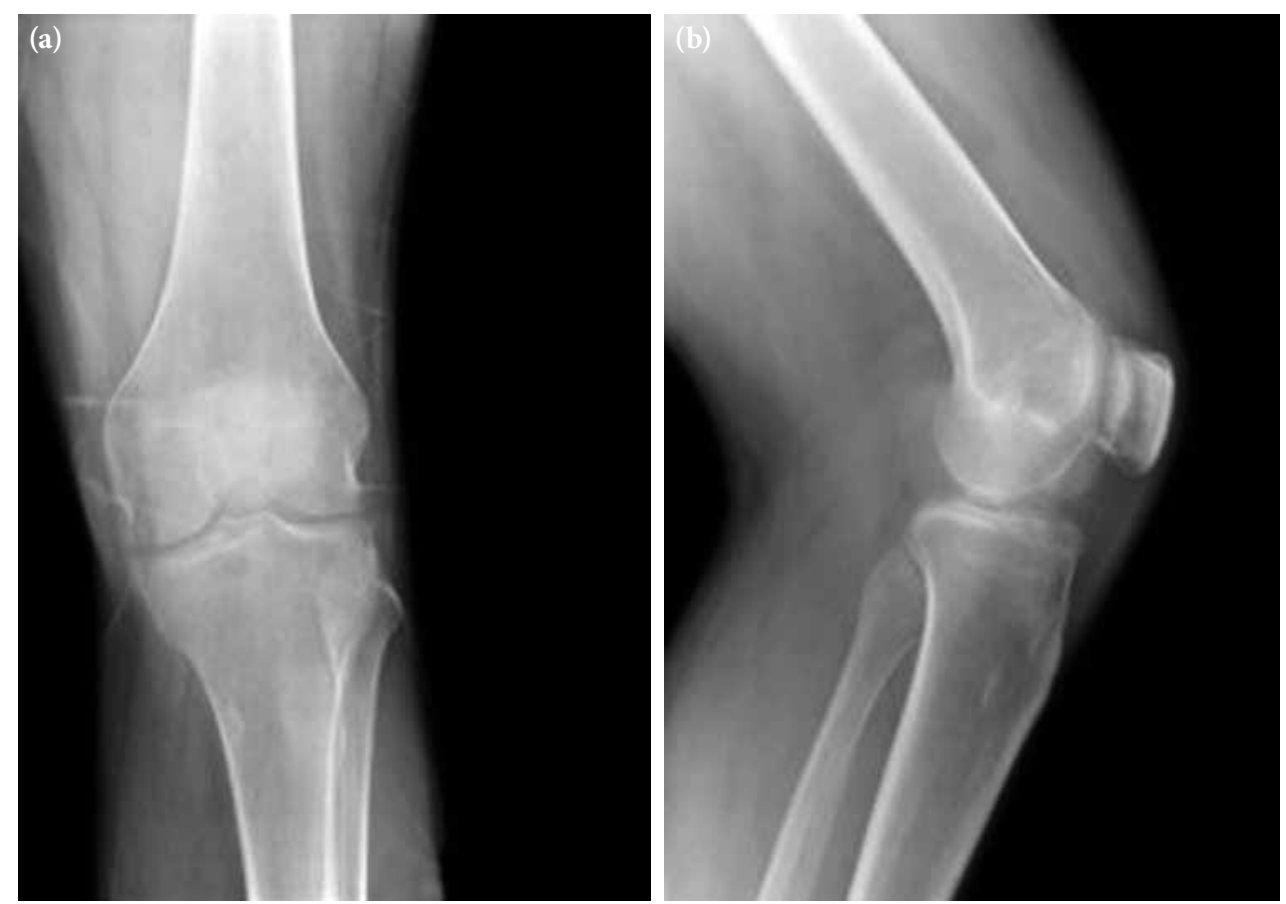

Figure 1. Shows anterior posterior and lateral views of the left knee. There is no abnormality detected. 

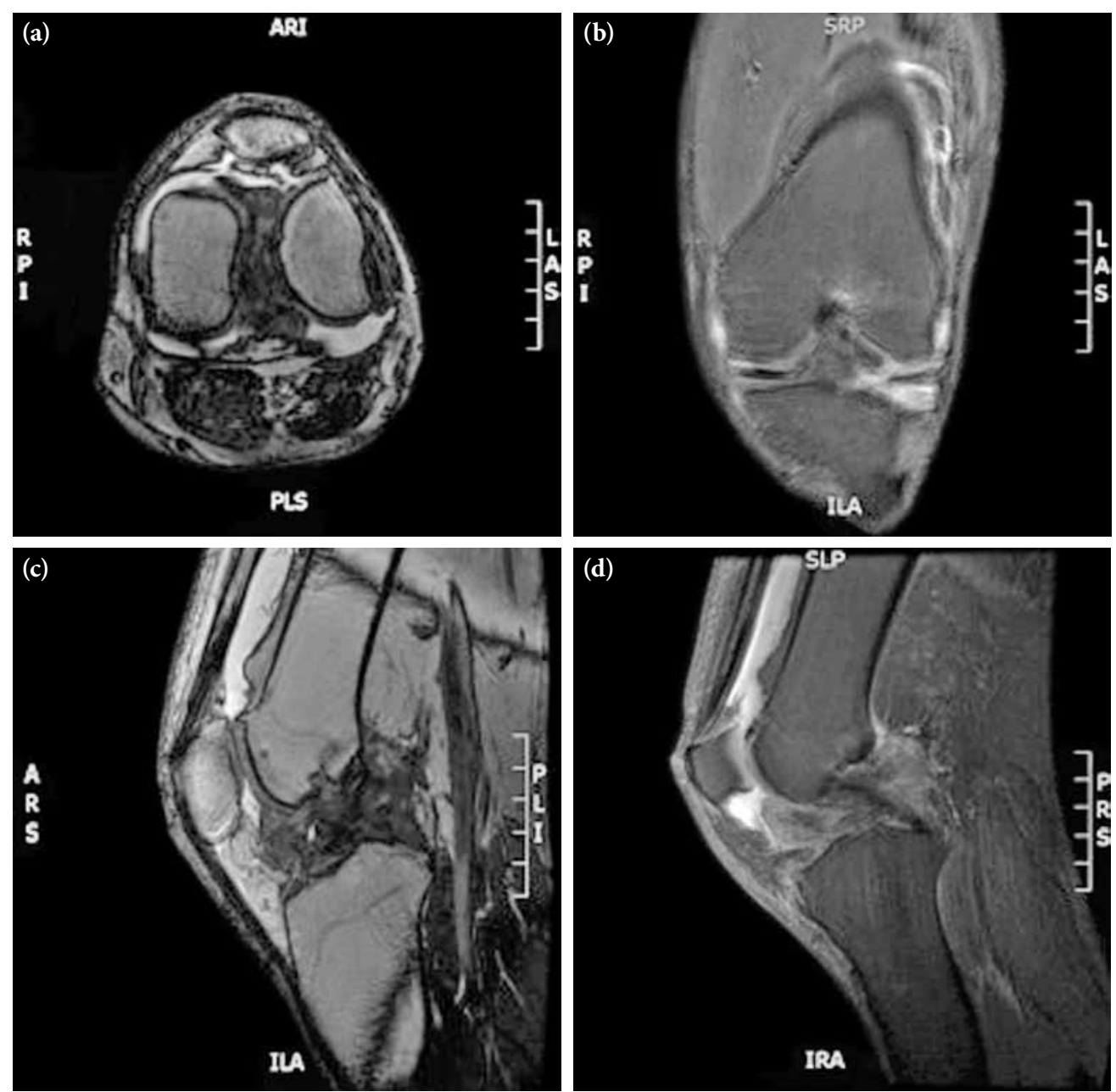

Figure 2. Magnetic resonance imaging of the left knee in axial, coronal and sagittal sections shows a nonspecific mass encasing the left anterior cruciate ligament and posterior cruciate ligament ligament; minimal joint effusion.

radiological diagnostic criteria for gout (not present in our case); and 4. The MRI showed a nonspecific enhancement which is not suggestive of gouty tophi. ${ }^{[1]}$

Synovial sarcomas occur predominantly in extremities where they tend to arise adjacent to large joints. They are intimately related to tendons, tendon sheaths, and bursa structures and are usually positioned just beyond the confines of the joint capsule. Joint cavity involvement has been reported to occur in less than $5 \%$ of patients. ${ }^{[4,5]}$ In the extremities, the single most common site for synovial sarcoma is the knee joint, followed by the ankle/foot, elbow, and upper arm/shoulder joint. Joint cavity involvement is rare, and the joint most commonly affected is the knee. Our patient presented with a locked knee with the mass located well within the joint cavity.
Gout is known to masquerade as several other medical conditions such as PVNS, chronic RA, chronic infectious arthritis, and amyloidosis as well as tuberculosis and malignancies. ${ }^{[6]}$

Intraarticular gouty tophi can lead to mechanical symptoms, but they rarely cause severe ambulatory disability in patients suffering from gout. Uric acid crystals can be deposited in tendons, ligaments, cartilage, bone, bursae and other synovial spaces, and para-articular spaces in the subcutaneous tissues. ${ }^{[6]}$ Soft tissue sarcomas, on the other hand, can also arise from muscles, tendons, fat, blood vessels, nerves, and synovial tissues, thus indicating the common sites between the two pathologies between gout and sarcoma.

Tophaceous deposits may appear as cysts or a focal sclerotic lesion when there is a calcium deposit within 


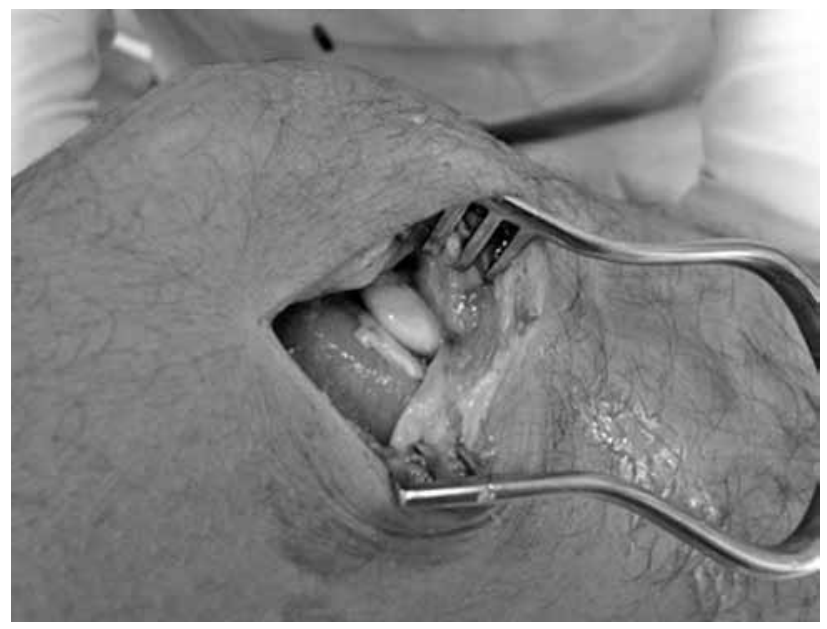

Figure 3. Intra-articular gouty tophi.

the tophi. The cysts may resolve following adequate control of the gout. Osteolysis that occurs in relation to tissue deposits of gout can mimic neoplasm. ${ }^{[6,7,8]}$

In early or even chronic gout, the features are normally negative on a plain radiograph.${ }^{[1]}$ A normal plain radiograph along with the suspicion of a meniscus injury prompted us to proceed with an MRI, and it was suggestive of synovial sarcoma or PVNS. This is not unusual as the appearance of tophaceous gout on an MRI is usually nonspecific. ${ }^{[6,9,10]}$ Therefore, an open biopsy was deemed necessary to come to a definitive diagnosis. We chose this over needle biopsy to ensure that we got an adequate tissue for sampling.

This patient had been diagnosed with gout five years prior to his presentation, and despite having developed complications such as renal calculi and multiple joint pains, he defaulted on his treatment and follow-up. This lack of adequate control led to the progression of the disease, causing impairment in function. It should be kept in mind that gout can present in such an atypical manner. ${ }^{[1]}$

Adequate control of gout is essential to prevent unusual complications of this disease, and it should always be considered as a differential when dealing with patients with a prior history.
In conclusion, gout can mimic any condition, even a locked knee or a sarcoma. In conclusion, gout can mimic any condition, even a locked knee or a sarcoma. Therefore, it should be considered as a plausible differential diagnosis in all cases.

\section{Declaration of conflicting interests}

The authors declared no conflicts of interest with respect to the authorship and/or publication of this article.

\section{Funding}

The authors received no financial support for the research and/or authorship of this article.

\section{REFERENCES}

1. Li TJ, Lue KH, Lin ZI, Lu KH. Arthroscopic treatment for gouty tophi mimicking an intra-articular synovial tumor of the knee. Arthroscopy 2006;22:910.e1-3.

2. Lu KH. Subcutaneous pigmented villonodular synovitis caused by portal contamination during knee arthroscopy and open synovectomy. Arthroscopy 2004;20:e9-13.

3. Cadman NL, Soule EH, Kelly PJ. Synovial sarcoma; an analysis of 34 tumors. Cancer 1965;18:613-27.

4. Andrassy RJ, Okcu MF, Despa S, Raney RB. Synovial sarcoma in children: surgical lessons from a single institution and review of the literature. J Am Coll Surg 2001;192:305-13.

5. Choong P, Pritchard D, Sim F, Rock M, Nascimento A. Long-term survival in high-grade soft-tissue sarcomaprognostic factors in synovial sarcoma. Int J Oncol 1995;7:161-9.

6. Melloni P, Valls R, Yuguero M, Sáez A. An unusual case of tophaceous gout involving the anterior cruciate ligament. Arthroscopy 2004;20:e117-21.

7. Talbott JH, Culver GJ, Mizraji M, Crespo DI. Symposium on gout; roentgenographic findings; description of a magnification technic. Metabolism 1957;6:277-96.

8. Resnick D, Niwayama G. Gouty arthritis. In: Resnick D, Niwayama G, editors. Diagnosis of the bone and joint disorders. 2nd ed. Philadelphia: W.B. Saunders; 1988. p. 1618-71.

9. Chen CK, Yeh LR, Pan HB, Yang CF, Lu YC, Wang JS, et al. Intra-articular gouty tophi of the knee: CT and MR imaging in 12 patients. Skeletal Radiol 1999;28:75-80.

10. Gentili A. Advanced imaging of gout. Semin Musculoskelet Radiol 2003;7:165-74.

11. Monu JU, Pope TL Jr. Gout: a clinical and radiologic review. Radiol Clin North Am 2004;42:169-84. 